\author{
Wahana Sekolah Dasar \\ Tahun .... Nomor ... Januari 2018 \\ Hlm 7-12 \\ Tersedia Online di http://journal2.um.ac.id/index.php/wsd/ \\ ISSN 0854-8293 (cetak)
}

\title{
TEKNIK MEMBACA SEKILAS (SKIMMING) DALAM MENINGKATKAN KEMAMPUAN MEMAHAMI TEKS NARASI
}

\author{
Baridatul Munawaroh, Suhel Madyono, Suwarti \\ PP3 Jl. Ir. Soekarno No. 1 Universitas Negeri Malang \\ e-mail: baridatulmunawaroh@gmail.com
}

\begin{abstract}
Abstak: Penerapan teknik membaca sekilas (skimming) dalam peningkatan kemampuan memahami teks narasi di kelas V SDN Ngreco Kabupaten Blitar. Penelitian dilaksanakan 2 siklus. Tahapan yang digunakan dalam setiap siklus meliputi Perencanaan, Pelaksanaan, Observasi dan Refleksi. Data yang diperoleh menggunakan metode wawancara, observasi, dokumentasi dan catatan lapangan. Teknik membaca sekilas dapat meningkatkan kemampuan memahami teks narasi.
\end{abstract}

Kata kunci: peningkatan, memahami teks narasi, teknik skimming

Membaca merupakan salah satu keterampilan berbahasa antara lain keterampilan menyimak, berbicara, dan menulis. Keterampilan membaca dapat dipelajari dengan berbagai cara. Adapun cara yang akan ditempuh harus sesuai dengan tujuan yang hendak dicapai dalam kegiatan membaca sesuai standar kompetensi dan kompetensi dasar. Dengan membaca diharapkan para siswa dapat memahami materi yang sedang mereka pelajari di kelas. Menurut Somadayo (2011:5) "Membaca adalah suatu kegiatan komunikasi interaktif untuk memetik serta memahami arti atau makna yang terkandung di dalam bahan tulis". Artinya pembaca berusaha memahami isi yang terkandung dalam bacaan. "Membaca adalah proses yang dilakukan serta dipergunakan oleh pembaca untuk memperoleh pesan, yang hendak disampaikan oleh penulis melalui media kata- kata/bahasa tulis" (Hodgson dalam Tarigan 2008:7). Berdasarkan uraian tersebut dapat disimpulkan bahwa membaca merupakan suatu kegiatan yang dilakukan untuk memahami isi dalam bacaan serta dipergunakan untuk memperoleh pesan yang terkandung dalam bacaan.
Keterampilan membaca ditanamkan sejak dini, untuk menarik minat baca siswa, salah satu cara dengan mengarahkan membaca bahan bacaan yang ringan seperti teks pendek seperti narasi. Bacaan yang tidak terlalu panjang akan mudah dipahami oleh siswa dan waktu yang digunakan untuk membaca relatif lebih singkat dibandingkan buku pelajaran. Ketika siswa sudah mulai menyukai kegiatan membaca maka guru akan mudah untuk memberikan bahan-bahan bacaan tambahan seperti membaca buku materi pelajaran.

Membaca berperan penting bagi keberhasilan siswa dalam mengikuti pelajaran. Bagi siswa kemampuan membaca merupakan kemampuan dasar yang harus kuasai. Oleh karena itu, pembelajaran membaca memiliki kedudukan yang penting dalam proses pembelajaran di sekolah. Pembelajaran membaca di sekolah dasar merupakan salah satu komponen dalam mencapai tujuan pembelajaran bahasa Indonesia terutama dan menjadikan siswa yang memiliki kemampuan atau keterampilan berbahasa Indonesia yang baik dan benar. 
Berdasarkan hasil observasi pada tanggal 09 Januari 2017 pembelajaran bahasa Indonesia di SDN Ngreco Kabupaten Blitar kelas $\mathrm{V}$ diperoleh bahwa pembelajaran dilakukan dengan menggunakan metode tanya jawab, tetapi metode yang digunakan guru tidak berjalan dengan baik karena siswa tidak ada yang mengajukan pertanyaan. Selain metode tanya jawab guru juga menggunakan metode diskusi tetapi siswa tetap gaduh di kelas.

Dalam mengatasi permasalahan tersebut digunakan suatu teknik pembelajaran yang dapat meningkatkan interaksi aktif antara siswa dengan guru atau siswa dengan siswa. Teknik pembelajaran ini dapat mengaitkan kemampuan membaca dan aktivitas siswa. Dalam meningkatkan kemampuan membaca siswa kelas V SDN Ngreco dapat dilakukan melalui teknik membaca sekilas (skimming). Menurut Soedarso (2010: 88) Skimming adalah tindakan untuk mengambil intisari atau saripati dari suatu hal. Artinya dalam membaca cepat dengan melihat dan memperhatikan bahan bacaan untuk mencari ide pokok dari suatu bacaan. Skimming dilakukan untuk melakukan pembacaan cepat secara umum dalam suatu bahan bacaan. Dalam skimming, proses membaca dilakukan secara melompatlompat dengan melihat pokok-pokok pikiran utama dalam bahan bacaan sambil memahami tema besarnya. Selain untuk melakukan pembacaan sekilas, skimming juga berguna dalam banyak proses membaca lainnya.

Proses pembelajaran dengan menggunakan teknik membaca sekilas berpengaruh terhadap peningkatan kemampuan memahami teks. Berdasarkan penelitian terdahulu yang dilakukan oleh penelitian penggunaan teknik Skimming oleh Paramita (2012) yaitu pada pembelajaran bahasa Indonesia dengan memahami isi teks bacaan di Kelas V SDN Tanjungsari 1 Kota Blitar, menunjukkan hasil pembelajaran memahami teks bacaan melalui membaca sekilas (skimming) dapat meningkatkan hasil kemampuan memahami teks siswa. Tulisan ini mendesripsikan penerapan dan peningkatan memahami teks narasi menggunakan teknik membaca sekilas

\section{METODE}

Pendekatan yang digunakan dengan pendekatan kualitatif dan jenis penelitian Penelitian Tindakan Kelas (PTK). Subjek penelitian ini adalah siswa kelas V di SDN Ngreco Kecamatan Selorejo, Kabupaten Blitar dengan jumlah siswa sebanyak 19 siswa yang terdiri dari 6 siswa laki-laki dan 13 siswa perempuan. Siswa kelas V dipilih sebagai subjek penelitian karena berdasarkan observasi yang dilakukan sebelum tindakan dan informasi dari guru kelas V SDN Ngreco, bahwa siswa kelas $\mathrm{V}$ rata-rata hasil belajar dalam memahami teks bacaan anak masih kurang maksimal.

Data dalam penelitian ini adalah data perencanaan, proses dan hasil kemampuan memahami teks narasi melalui membaca sekilas (skimming). Data pada tahap perencanaan meliputi kegiatan guru kelas V SDN Ngreco saat melakukan pembelajaran membaca sekilas di kelas dan nilai hasil tes memahami isi teks siswa. Sedangkan data proses diperoleh dari kegiatan pembelajaran membaca teks narasi dengan teknik membaca sekilas pada siklus I dan siklus II. Selanjutnya, Data hasil diambil dari penilaian proses dan produk. Data penilaian proses diperoleh dari aktivitas siswa selama proses pembelajaran memahami teks narasi melalui membaca sekilas (skimming) pada saat siklus I dan siklus II berlangsung. Data penilaian produk diperoleh dari hasil tes pada kegiatan pembelajaran siklus I dan siklus II. Sumber data dalam penelitian ini adalah siswa kelas V SDN Ngreco Kecamatan Selorejo, Kabupaten Blitar tahun pelajaran 2016/2017. Sedangkan sumber data lainnya berasal dari guru kelas V SD. Teknik pengumpulan data dengan metode observasi, tes, dokumetasi, wawancara dan catatan lapangan. Data dianalisis dengan reduksi data, penyajian data dan penarikan kesimpulan. 


\section{HASIL}

Pembelajaran memahami teks narasi di kelas V SDN Ngreco Kabupaten Blitar pada tahap pratindakan belum terlaksana dengan baik, tingkat keaktifan dan kerjasama masih rendah, teknik membaca yang digunakan guru dalam pembela-jaran yang diterapkan guru membuat siswa bosan saat mengikuti pelajaran, mereka hanya membaca bacaan yang diberikan oleh guru tanpa memahami isi dari bacaan tersebut dan hasilnya ketika diberi pertanyaan siswa masih bingung. Selain itu, dalam pembelajaran siswa kurang antusias dan masih banyak siswa yang ramai sendiri. Nilai ketuntasan klasikal kemampuan memahami teks siswa juga masih rendah dengan ratarata 50. Agar kemampuan memahami teks siswa kelas $\mathrm{V}$ dapat meningkat diperlukan teknik pembelajaran yang tepat yang dapat mengaitkan kemampuan membaca dan aktivitas siwa.

Berdasarkan permasalahan tersebut, perlu adanya perbaikan yaitu guru hendaknya menggunakan teknik-teknik membaca yang bervariasi seperti membaca nyaring dan membaca dalam hati, siswa juga diberikan teks bacaan yang berbeda-beda agar siswa tidak bosan serta lebih aktif dalam pembelajaran bahasa Indonesia,

Berdasarkan hasil observasi, catatan lapangan serta nilai hasil keterampilan yang diperoleh pada pembelajaran siklus I, maka refleksi pada siklus I pertemuan 1 terdapat 2 komponen yang tidak dilakukan guru yaitu, pada kegiatan inti pada sintak lanjutkan pada paragraf selanjutnya masih ada siswa yang tidak tahu bahwa mereka harus menggaris bawahi bagian-bagian yang dianggap penting dan guru belum membimbing siswa agar bekerja secara kelompok. Pada pertemuan 2 terdapat 1 komponen yang belum dilaksanakan yakni pada sintak bacalah beberapa kata pada setiap paragraf, masih ada kelompok yang bingung ketika diminta untuk mencari katakata yang penting serta ide pokok yang terdapat pada bacaan. Rata-rata persentase aktivitas guru pada siklus I sebesar $85 \%$ dalam kriteria B (baik). Kegiatan yang perlu ditingkatkan guru antara lain suara kurang lantang, harus memberikan instruksi yang jelas, membimbing siswa dalam mencari hal-hal yang dianggap penting dan guru juga harus menanamkan kepada siswa rasa toleransi ketika melakukan dis-kusi bersama.

Rata-rata presentase pencapaian aktivitas siswa pada siklus I adalah $73 \%$. Guru perlu memotivasi siswa yang belum aktif dalam pembelajaran dan meningkatkan rasa percaya diri siswa saat presentasi. Guru hendaknya juga mengkondisikan suasana kelas agar lebih tenang. Nilai rata-rata kemampuan memahami teks narasi pada siklus I telah mengalami peningkatan dari 50 menjadi 57, sedangkan rata-rata persentase keberhasilan menulis deskripsi siswa masih 32\% dengan kriteria $\mathrm{E}$ (tidak baik). Ketuntasan klasikal belum mencapai target yang ditetapkan yaitu $80 \%$, sehingga penelitian perlu dilanjutkan ke siklus II.

Berdasarkan hasil observasi, catatan lapangan serta nilai hasil kemampuan yang diperoleh pada pembelajaran siklus II, guru sudah melakukan langkah-langkah pembelajaran menulis deskripsi dengan baik. Persentase aktivitas guru pada siklus 2 mencapai $100 \%$ dengan kriteria A (sangat baik). Berdasarkan catatan lapangan diketahui kegiatan pembelajaran yang dilakukan guru berjalan dengan lancar dan menyenangkan.

Persentase aktivitas siswa pada siklus ini sebesar 93\% dengan kriteria A (sangat baik), dengan demikian dapat diketahui bahwa proses pembelajaran memahami teks narasi melalui teknik membaca sekilas sudah baik. Siswa juga dapat membandingkan isi dua teks dengan benar serta dapat mencari kata-kata penting yang berhubungan dengan teks yang mereka baca.

Nilai hasil kemampuan siswa dalam memahami teksnarasi juga mengalami peningkatan. Nilai rata-rata pada pertemuan 1 maupun pertemuan 2 sudah mencapai KKM yang ditentukan. Secara umum siswa sudah dapat 
memahami teks naasi yang mereka baca dengan baik, semua siswa tutas dalam mengerjaka tes yang diberikan karena sudah dapat memahami teks bacaan yang mereka baca dan memahami soal yang diberikan guru. Persentase ketuntasan belajar klasikal telah melebihi $80 \%$, sehingga penelitian pada siklus II dinyatakan tuntas dan tidak perlu dilanjutkan ke siklus berikutnya.

\section{PEMBAHASAN}

\section{Penerapan Teknik Membaca Sekilas}

(Skimming) pada Pembelajaran Bahasa Indonesia Membandingkan Dua Teks di Kelas V SDN Ngreco Kabupaten Blitar

Pelaksanaan pembelajaran bahasa dengan teknik skimming siklus I berjalan dengan baik. Terlihat dari pencapaian aktivitas guru siklus I sebesar $80 \%$ pada pertemuan 1 , dan mencapai $90 \%$ pada pertemuan 2 . Hal ini menunjukkan bahwa guru belum maksimal dalam melaksanakan pembelajaran. Sebesar 20\% aktivitas guru belum muncul pada pertemuan 1 , dan sebesar $10 \%$ pada pertemuan 2 . Aktivitas yang belum muncul diantaranya penyampaian informasi bahwa siswa harus menggaris bawahi kalimat yang dianggap penting, dan masih ada siswa yang tidak mau bekerjasama. Sementara aktivitas siswa siklus I sebesar $73 \%$. Pada siklus I siswa terlihat senang dan bersemangat mengikuti pelajaran. Aktivitas siswa membaca baik, siswa dapat mengetahui cara khusus untuk mencari ide pokok yang terdapat dalam suatu bacaan secara singkat. Hal ini sesuai dengan langkah-langkah membaca sekilas yang disampaikan oleh Rahim (2008: 64) yaitu "(1) baca beberapa kalimat, (2) lanjutkan pada paragraf berikutnya, (3) bacalah hanya beberapa kata pada setiap paragraf, dan (4) kerjakanlah selalu dengan cepat, agar efisien membaca hendaknya dilakukan dengan waktu yang singkat"

Pada pembelajaran siklus I ada beberapa permasalahan yang muncul. Permasalahan tersebut antara lain suara masih kurang lantang dan ada instruksi yang belum disampai- kan yaitu memberi tanda garis bawah pada bacaan yang dianggap penting. Guru diharapkan memberikan instruksi dengan suara yang lantang agar siswa dalam satu kelas dapat mendengarkan instruksi dengan jelas. Terdapat beberapa siswa yang tidak mau bekerjasama dan memilih untuk mengerjakannya sendiri, guru hendaknya memberikan penjelasan bahwa dengan bekerja kelompok itu tugas dapat selesai dengan tepat waktu karena jawaban yang sulit dapat dibahas secara berkelompok. Guru masih terfokus kepada kelompok tertentu sehingga masih ada siswa yang belum paham ketika diminta untuk menuliskan gagasan pokok yang terdapat pada bacaan, guru hendaknya berkeliling di setiap kelompok agar siswa yang belum paham tentang tugasnya dapat langsung bertanya kepada guru.

Pembelajaran bahasa Indonesia dengan menggunakan teknik membaca sekilas (skimming) di siklus II telah berjalan dengan sangat baik. Terlihat aktivitas guru siklus II sebesar $100 \%$ pada pertemuan 1 dan 2 . Peningkatan aktivitas guru pada siklus II sangat baik karena guru sudah lebih mengenal siswa dan sudah terlatih selama mengajar pada siklus I. kekurangan pada siklus I telah diperbaiki pada siklus II, sehingga seluruh kegiatan guru yang direncanakan telah muncul pada siklus II. Aktivitas siswa dilaksanakan dengan sangat baik oleh siswa. Nilai aktivitas siswa pada siklus II mencapai $89 \%$ pada pertemuan 1 dan 96\% pada pertemuan 2. Aktivitas siswa sangat baik karena guru memberikan motivasi dan hadiah kepada siswa untuk aktif dalam pembelajaran. Teknik membaca skimming telah berhasil meningkatkan interaksi antara siswa dengan guru atau siswa dengan siswa dan hasil belajar pada muatan bahasa Indonesia. Hal ini sependapat dengan Hery Firman yang mengemukan hasil penelitian bahwa penerapan teknik Skimming dapat berpengaruh dalam meningkatkan kemampuan membaca paragraf eksposisi. 


\section{Peningkatan Hasil Kemampuan \\ Memahami Teks Narasi Materi Membandingkan Dua Teks di Kelas V SDN Ngreco}

Pemberian tugas dapat meningkatkan kemampuan siswa dalam memahami isi teks yang telah dibaca. Kemampuan membaca siswa bacalah beberapa kata setiap paragrafdan kerjakanlah selalu dengan cepat mengalami peningkatan dari kurang baik menjadi sangat baik. Masih rendahnya kemampuan membaca siswa pada siklus I disebabkan siswa kurang memahami pertanyaan yang terdapat pada lembar soal.Permasalahan ini dapat diatasi pada siklus II melalui motivasi dan bimbingan kepada siswa. Terbukti siklus II pertemuan 2 kemampuan membaca siswa sangat baik, siswa yang kemampuan membacanya sangat baik sejumlah 17 anak.

Nilai hasil belajar yang dicapai siswa mengalami peningkatan secara ber-tahap mulai dari pratindakan, siklus I dan siklus II. Nilai hasil belajar pratindakan 50 meningkat sebesar 7 poin pada siklus I pertemua 1 menjadi 57 , dan meningkat 16 poin pada pertemuan 2 menjadi 73.Kemudian pada siklus II pertemuan 1 meningkat sebesar 8 poin menjadi 81 , dan pada sikus II pertemuan 2 meningkat sebesar 6 poin menjadi 87. Sedangkan pada pratindakan diketahui11\% siswa mencapai KKM, pada siklus I pertemuan 1 diketahui $16 \%$ siswa mencapai KKM, dan pertemuan 2 diketahui 47\% siswa mencapai KKM. Pada siklus II pertemuan 1 diketahui $74 \%$ siswa mencapai KKM dan pada pertemuan 2 diketahui 100\% siswa mencapai KKM. Ketuntasan klasikal pada siklus II sudah memenuhi standar yang telah ditentukan yaitu sebesar $80 \%$. Dengan demikian siswa dapat memahai materi yang dipelajari dengan membaca sekilas (skimming), seperti pendapat Yana (2015) bahwa dengan membaca sekilas maka siswa: (a) mudah mengenali topik bacaan, (b) mengetahui pendapat dan pemikiran orang lain dengan singkat, (c) mengingat kembali apa yang sudah dibaca, dan (d) menghemat waktu. Dengan demikian dapat dikatakan bahwa penerapan teknik skimming pada pembelajaran bahasa Indonesia materi membandingkan 2 teks dilaksanakan dengan sangat baik dan ketuntasan belajar klasikal yang sangat baik di kelas V SDN Ngreco. Hal ini sesuai dengan hasil penelitian yang telah dilakukan oleh Paramita pada tahun 2012, yang melakukan penelitian tentang penerapan teknik membaca skimming mata pelajaran bahasa Indonesia pada materi memahami teks bacaan dapat meningkatkan kemampuan membaca siswa kelas V SDN Tanjungsari 1 Kota Blitar

\section{SIMPULAN DAN SARAN}

Penerapan teknik membaca sekilas (Skimming) pada peningkatan kemampu-an memahami teks narasi di kelas V SDN Ngreco Kabupaten Blitar, menciptakan interaksi aktif antara siswa dengan guru, atau siswa dengan siswa. Aktivitas guru dan siswa dalam pembelajaran mengalami peningkatan. Aktivitas guru pada siklus I pertemuan 1 sebasar $80 \%$ dengan kategori baik, meningkat menjadi $100 \%$ pada siklus II pertemuan 2 dengan kategori sangat baik. Sementara aktivitas siswa pada siklus I pertemuan 1 sebesar 69\% dengan kategori kurang baik, meningkat menjadi 96\% pada siklus II pertemuan 2 dengan kategori sangat baik.

Penerapan teknik membaca sekilas (Skimming) dapat meningkatkan kemam-puan memahami teks narasi di kelas V SDN Ngreco Kabupaten Blitar, Hal ini ditunjukkan dari nilai rata-rata hasil kemampuan siswa dalam menuntas-kan sola yang diberikan guru, siswa yang semula 50 pada pra tindakan meningkat pada siklus I pertemuan 2 menjadi 73. Dan meningkat lagi pada sikus II pertemuan 2 menjadi 87. Sedangkan pada pra tindakan diketahui $11 \%$ siswa mencapai KKM, padasiklus I pertemuan 2 diketahui $47 \%$ siswa mencapai KKM dan pada siklus II pertemuan 2 diketahui 100\% siswa mencapai KKM. Dalam pelaksanaan pembelajaran teks narasi untuk meningkatkan kemampuan siswa dengan teknik membaca sekilas (Skimming) 
DAFTAR RUJUKAN

Arikunto, Suharsimi dkk. 2010. Penelitian Tindakan Kelas. Jakarta: Bumi Aksara

Firman, Hery. 2014. Penerapan Teknik Skimming dan Scanning Dalam Meningkatkan Kemampuan Membaca Paragraf Eksposisi Siswa Kelas X TKJ SMK Negeri 1 Bintan Tahun Ajaran 2013/2014. Skripsi. Tanjung Pinang: UMRAH

Rahim, Farida. 2008. Pengajaran Membaca di Sekolah Dasar. Jakarta: Bumi. Aksara.

Somadayo, S. 2011. Strategi dan Teknik Pembelajaran Membaca. Yogyakarta: Grahailmu
Standar Nasional Pendidikan. 2006. Jakarta: Kementerian Pendidikan dan Kebudayaan Sugiyono. 2010. Metode Penelitian Kuantitatif , Kualitatif dan R\&D. Bandung: Alfabeta Tarigan, Henry Guntur. 2008. Membaca Sebagai Suatu Keterampilan Membaca. Bandung: Percetakan Angkasa

Yana, Y. 2015. Manfaat Membaca Cepat Hambatan dan Cara Mudahnya. (http:// manfaat.co.id/manfaat-membaca-cepathambatan-dan-cara-mudahnya) diakses pada 16 Januari 2017 